What is a Book? Redefining the Book in the Digitally Social Age

Miriam J. Johnson, Oxford Brookes University 


\begin{abstract}
This article focuses on what is meant by the term 'book'. Here, there is a consideration of how the definition of the book has altered over time as technology has improved and as writers themselves began to have different relationships to the book and industry. It further explores the ways the book itself has altered in format, from printed to digital, with audio editions, and socially in relation to the rise of social media and a new form of author who chooses to write and share their works directly within social platforms. In this context, book must be redefined to incorporate the context of new social technology.
\end{abstract}

Key Words: Authors, Book, Publishing, social media

\title{
What is a Book? Redefining the Book in the Digitally Social Age
}

This article seeks to examine changing ways of thinking about the 'book' and how new technologies and social media platforms are perceived in this context. To do so, it analyses a question central to this exploration: What is a book? The literature critically examined in this article is viewed through a theoretical background anchored within Foucault's idea that "the frontiers of a book are never clear cut" (Foucault, 1989, p. 23) and Marshall McLuhan's rear-view mirror (McLuhan \& Fiore, 2008).

This article explores the changing definitions of the book in relation to the growth of new technologies. I first takes into account the way the 'book' continues to change with the advent of new technologies. The role of innovative formats as a means of disrupting the discourse is considered alongside the move from books being printed bound objects 
to content in a container that alters for different types of outputs. The article ends by drawing together arguments on how the book in the current climate must take into account the digital sociality of the global village and the role of the book within that space.

\section{Changing definitions of a book}

With continual changes within the industry, as new technologies and media converge and grow both vertically and horizontally, the definition of a book must capture the essence of content, while remaining fluid enough to encompass existing and future packaging. In order to facilitate a suitably adaptable and forward-thinking definition of the book it is necessary to first understand how the book is currently defined in the different sites of enquiry and who has the authority to pronounce.

From the time of inscribed clay tablets (2500 B.C.E.) until the digital revolution (1990s), a book has been a physical object that was usually portable, often collected, and prized as a "storehouse of human knowledge" (Kilgour, 1998, p. 3). The book itself has undergone physical changes over time and book historians now use "the word 'book' in its widest sense, covering virtually any piece of written or printed text that has been multiplied, distributed, or in some way made public" (Eliot \& Rose, 2007, p. 3). While this definition invites inclusivity for new forms of technologically produced writing, it is as vague as it is broad, and the question remains as to how this definition can evolve more specifically to encompasses new, as of yet undiscovered, forms of the book that develop in the blanks and gaps within the wider discourse.

Historically, the book publishing industry has enjoyed long periods of stability followed by revolutionary upheavals that led to radical changes in the way that books were written, published, and distributed. The most easily recognised shift is from the 
codex (AD 150) to the printing press (AD 1450), which gave rise to the traditionally bound books that we have today. Other technological advances such as magazine printing, mass-market paperbacks, and eBooks have also come of age in recent decades and have contributed to the evolving definition of a book by changing the format of a book in such a way that it retains tight connections, real or virtual, with the physical book.

Digital publishing and the convergence of new technologies have altered the available formats of the book, and we must, in turn, alter the discourse surrounding the book to reflect this change. In discussing ways that the themes of continuity (in this case, the definition of the book) can be hindered by preconceptions, a good starting place is Foucault, who, in his Archaeology of Knowledge, states that to best prepare ourselves for understanding a discourse "we must rid ourselves of a whole mass of notions," in this case, the set descriptors of a book. He goes on to explain that the specific notions "that must be suspended above all are those that emerge in the most immediate way: those of the book and the oeuvre" (1989, pp. 23-23).

Foucault alludes to the coming evolution of the book when he states that "The book is not simply the object that one holds in one's hands; and it cannot remain within the little parallelepiped that contains it" (1989, p. 23). By stripping out the "interpretation of the facts" (p. 29) about what a book is, we can better define a book by looking at the "rule of simultaneous or successive emergence of the various objects that are named, described, analysed, appreciated, or judged in that relation" (p. 32). In doing so, Foucault suggests that we:

tear away from their virtual self-evidence, and to free the problems that they pose; to recognise that they are not the tranquil locus on the basis of which other questions (concerning their structure, coherence, systematicity, 
transformations) may be posed, by that they themselves pose a whole cluster of questions. (p. 26)

In defining a book we must ask: how is it changing, and how does it relate to content, containers, and digital sociality?

\section{How is a book changing?}

At the Shenzhen-UNESCO International Conference on "Digital Books and Future Technology", Hitchens touches on the evolution of the book when he predicts that publishers and distributors will be "evolving from their more traditional role as book publishers to content providers in the form of eBooks and ePublications" (2014, p. 3). This is evident with readers of eBooks rising 11\% in the years 2012 to 2014 (Zickuhr \& Rainie, 2014) and it is expected to jump again to see "e-books' share of consumer book revenue exceed 40\%" in markets with high tablet penetration (PWC, 2015, point 3).

While Hitchens does mention how "digital companies will most likely join the fold as publishing companies shift resources towards the burgeoning eBook industry," (2014, p. 13), he neglects to go further to examine how this shift will encompass media more broadly, and only hints at the digitally social communities that can grow up around a published product, and not the power these shifts contain. He does, however, suggest that "that the future of eBooks will be based on much more than text on a screen" (2014, p. 13). This can already be seen in the marketplace with publications such as Faber \& Faber's interactive book app of T.S. Eliot's of The Wasteland, or the children's book apps The Little Pirate or Rasmus Klump, which are a few best-selling examples of converging, ePublication technology. Hitchens concludes that "the demise of the physical book is still far from inevitable," (2014, p. 16). Thus far, the numbers 
agree, with the latest PEW research showing that $69 \%$ of American adults have read at least one printed book in 2014 (Zickuhr \& Rainie, 2014).

Phillips, in his book Turning the Page: The Evolution of the Book, explores the current state of the book and its future potential. He discusses its forms and labels printed books 'pbooks' as a way of acknowledging that although published products are often called books, "traditional routes of production are being left behind" (2014, p. xiii). The definition of a book is broadening in accordance with changes in power strategies, communities, and authorship.

Changes within the publishing industry, which subsequently impact the definition of the 'book', have not always been easily accepted. In 1998, Kilgour wrote that the eBook "has met with an unenthusiastic reception, chiefly because it presents a radical physical change for the user: from the familiar bound book in the hand to the monitor screen of a desktop computer or the flat-panel display of a laptop machine" (p. 151). By 2006, when Kelly wrote that "publishers have lost millions of dollars on the long-prophesied e-book revolution that never occurred" (2006, p. 2), eBooks had become an accepted, if still unpopular, form of the book that echoed the physical book in the rear-view mirror, but one that is held under glass.

Traditionally, anything bound between two covers and distributed could potentially be considered a book. This includes books with no words, such as picture books, coffee table, and photography books. Moving away from the traditional formats, if we took the content out of the container what is there to define a 'book'? Let's take, for example, a trade bestseller. The publishers distribute it in hardback, paperback, eBook formats, all of which are comfortably considered to be 'books'. But what happens when the publisher converges media and creates an audiobook that resembles the bestseller only in that the content, not the format, is (mostly) the same? 
Is an audio book still a book? Bhaskar suggests an answer in saying that "Audiobooks are a halfway house - at one level they are sound, at another just another format of a text like a paperback or an eBook" (2013, p. 32). Is it, as Bhaskar states, "sufficiently close to a book to easily absorb the associations of 'book publishing"' (p. 32) or does it fall outwith commonly accepted definitions of the book? This links to the seeming contradiction that lies between the repeatability of the framework of the book as an understood and recognisable object in the discourse, and the un-repeatability of specific statements within that framework which allows new formats of the book to develop (Foucault, 1989).

As such, Eliot and Rose state that a book is a text that has been "multiplied, distributed, or in some way made public" (2007, p. 3), but this definition lacks clarity in two key ways. Firstly, the issue of multiplication, distribution, and making public must be scrutinised, as each of these elements limit the definition of a book. When a book is defined by being "in some way made public," Eliot and Rose seem to discount those books that are printed and never made public at all, such as pulped books and private print runs that sit in a room, never shared. Bhaskar also disagrees with the usefulness of the phrase 'to make public' by claiming that the "weakness of such a view lies in the lack of clarity about making public" (2012, p. 168). When there is no clarification of what 'making public' means, do then the elements of multiplication and distribution take precedence and the non-public, non-distributed item still retain the nomenclature of a book simply by virtue of being multiplied or in some way distributed? Likewise, would a single issue of a bespoke photography or picture book be unable to be considered a 'book' due to its lack of printed text, multiplication, public exposure, or distribution?

The single issue, bespoke book that pokes holes in the far edges of Eliot and Rose's definition is not the norm, and can, perhaps, be glossed over in favour of the 
inclusivity their definition provides, where it can include print on demand and single edition prints. However, the second, more pressing issue with their definition deals with their lack of engagement with terms that specifically relate to technological advances or the sociality that, in many ways, is driving the current market. In their omission, Eliot and Rose are playing it safe by keeping their definition from aging. But the vagueness which keeps this definition of the 'book' alive and modern is also what makes their understanding of the 'book' an umbrella term that prevents it from becoming contextually relevant when engaging with future technologies.

Where Eliot and Rose fail, Cope and Phillips step in, going a step further, claiming that "A book is no longer a physical thing. A book is what a book does" (2006, p. 7). The question that naturally follows from this is: what does a book do? According to Cope and Phillips a book does two things:

- They have a characteristic textual, and thus, communicative, structure.

- They have book-like functions because they are defined, registered and recognised as books. This means that, when we need to 'do books', they can be found in bibliographical listings, they are acquired through bookstores and libraries; and they can be referenced as books. (2006, pp. 7-8)

This duel-definition of what a book does creates areas of friction within itself, the most obvious of which is where Cope and Phillips mention the "characteristic textual, and thus, communicative structure". Within this statement there seems to be lacking a theoretical or practical link between a book's textuality and its communicative structure. What is there to presuppose that a book's text is communicative? Cope and Phillips overstate the connection between these two elements by presuming that because the structure is textual is it also communicative, where, in fact, the 
communicative nature of a text is potential instead of actual. Again, we can use the aforementioned example of the book that was published but never read, or printed and then pulped without trying to sell a single copy. These examples show text in its potential to be communicative, but also highlight that one does not necessarily lead to the other.

In looking at their second point in what a book does, we must question the 'booklike' functions they describe. Do Cope and Phillips mean functions that are currently attributed to the word 'book'? Or to the physical object a 'book' represents? Does a book have to consist all of these attributes mentioned, or just one? And, most importantly, where does this allow room for newer formats of the book such as Keitai Shōsetsu, collaborative fiction, and social media writing, which, noticeably, lack some of the features mentioned above?

Cope and Phillips write earlier that a book is "a structured rendition of text and possibly also images" (2006, p. 7), which they quickly narrow down as "extended text (of, say, more than twenty thousand words and/or twenty images)" (2006, p. 7). To truncate the length of text considered to be a book overlooks a wide array of genres, presentation styles, and eproductions that all, rightfully, should fall under the mantle of the book. By narrowing down the understanding of a text as it relates to their interpretation of a book, Cope and Phillips undermine an open and forward-thinking definition of what a book is and can be.

\section{Innovative Formats}

In 2008 and 2009, Bob Stein, co-founder of The Institute for the Future of the Book, hit on the community-driven definition of a book and began to describe the "future of the book as 'a place where readers (and sometimes authors) congregate'” (2008). By taking 
a book out of its static printed or locked digital form and opening it up to become a meeting place for authors and readers, Stein envisioned the book publishing industry to be less about the book as an object and more about the content and the dialogue created in and around communities of reading and writing. With this in mind, the Institute for the Future of the Book ran several projects around generating collaborative dialogues in the margins of a digital book, including "The Golden Notebook Project".

This was a collaborative project in which seven readers were asked to conduct a conversation in the digitally provided margins of an online version of Doris Lessing's The Golden Notebook. The website for the project seems to be stagnate, but by clicking through to the "read the book" section, where any reader can gain access to the same text that the original seven read and commented on, the user is faced with an onscreen design that mimics the pages of printed book. In fact, along with clicks left and right to change pages, at the top of the interface there are changeable fields which tell readers how the online, UK print, and USA print versions correlate page by page. The rear-view mirror aspect of the interface serves to remind users, who may have been unfamiliar with onscreen reading of novels when the project was begun in 2008 , that what they see onscreen directly corresponds to a printed page, lending the screen version a sense of legitimacy (McLuhan \& Fiore, 1968).

A traditionally published book that has been moved online, where comments on the text are allowed without altering the original 'book', does not in and of itself, as Stein seems to suggest, create a future where the definition of a book expands to become a place of communication. However, there is scope for the dialogue in digitally social places to give rise to a book. This is explored by Phillips, who discusses the social platforms of blogs as places that have "attracted a whole new set of writers" (2014, p. 16). Many printed books have been pulled together from blog feeds creating what is 
know as a 'blook'. Some of these, such as Julie Powell's Julie and Julia - a blog based on the author's adventure of using a printed version of a famous cookbook for a year - later shifted media again to be made into a film. Printing blooks even gave rise to a Blooker prize that was run by Lulu.com in 2006 and 2007, further legitimising the content of blogs by rewarding the efforts of publishers to pull the content offline and issue it in a traditional format.

However, as publishers got wind of the marketability of blooks, they sent larger advances to the authors, eventually becoming unsustainable as a business model. At this point publishers, for the most part, abandoned the process of pulling blogs offline into traditional publication, as Pack, formerly of Unbound, said, "publishers tend to get very excited about things and then ruin it very quickly" (2016, 19:37).

Both Phillips and Bhaskar briefly address the rise of new writing outlets in the Asian market, specifically looking at mobile storytelling forms of Keitai Shōsetsu in the Japanese market and what Bhaskar calls Original Fiction from China. Keitai Shōsetsu “are novels being written on cellular phones, or keitai's, by individuals in Japan. These novels are tapped out on mobile phones in a form similar to long text messages" (Keckler, 2012, p. 2). The rise of mobile fiction in Japan has been heavily intertwined with the proliferation of cell phone usage, especially among young adults and young women, who are most often the readers and writers of the form (Keckler, 2012). Authors in Japan pen their stories on their phones when they have time and upload them to dedicated websites such as Maho no i-rando, which was followed by Magic iland and Wild Strawberry, among others.

In China, the market shifts away from phone-written fiction and focuses instead on websites that act as portals for readers to find and read new original fiction. Reading Base, a mobile platform run by the country's largest mobile provider China Mobile is 
just one of the dedicated Original Fiction outlets that are helping to fuel the " 5 billion yuan industry" (Bhaskar, 2012, p. 52). The platforms in China work on a freemium model where a user has free access to some content and has to pay for others. "Popular work is upgraded to pay-as-you-go VIP areas" (Bhaskar, 2012, p. 52).

Keitai Shōsetsu and China's Original Fiction have generally been accepted as new genres of fiction, as Bhaskar says, but at what points can they be considered books? Does the format of the printed book still retain privilege as the prized goal that only then allows a work to be called a book? It would seem as such, with journalist Normitsu Onishi pointing out in 2008 that “Of last year's 10 best-selling [printed] novels, five were originally cellphone novels" (2008, para 2). Similarly, in China, one step beyond the pay-as-you-go VIP area, there are publishers that are dedicated to bringing the most popular works to the printed page.

In the West, communities of writing that would often remain unknown outside of their genres have suddenly given rise to culturally influential, best-selling authors, of the most famous of which is E. L. James. Much like Keitai Shōsetsu and Original Fiction, these works, written within or uploaded to, community websites and repositories online "represent new ways of writing and a new end product" (Bhaskar, 2012, p. 52). Such works are often written and exist in an entirely digital setting, which could seem undermine the validity of calling them 'books', but this would be a mistake. Writing repositories online are prime slush piles for publishers, with the added benefit that the slush has sometimes already been filtered (the VIP area in China, fan fiction with the highest views in the West) and the publishers can choose to bring books to print that already receive a high number of views and are likely to sell well in traditional containers. 


\section{Content and Containers}

Early in his discussion of the book, Phillips declares "The whole debate over print vs. digital is over" (2014, xii). Certainly the debate has calmed down since the sudden upheaval of digital publishing spurred academics and industry experts to write books and articles such as: The Book Is Dead (Long Live the Book) (Young, 2007), 'Books Survive the Orgasm of Closure' (Mathews, 2008), and 'Flogging a Dead Book?' (James, 2011), amongst others. While it is true that there is less concern that print is dead, there is a new debate arising about how digital and communicative technology can redefine the book and is reshaping the publishing industry as a whole.

Foucault notes that "the unity of the book, even in the sense of a group of relations, cannot be regarded as identical in each case" (Foucault, 1989 p. 23). Lichtenberg also addresses the lack of unity in the format of the book in saying that "With the book, since Gutenberg, the form factor itself defined both container and content." He goes on to say that "The internet and digital technologies have broken them apart" (2011, pp. 105-106).

Bhaskar mentions how:

We still talk of 'the book' both as the physical codex on our shelf but also as 'the text' or 'the work' in a more abstract sense; moreover we use these distinct terms interchangeable [...] suggesting we do not, in day-to-day circumstances, recognise a disjuncture between content and media. (2012, p. 80)

Much of what Bhaskar discusses relating to the content and context of the publishing industry is influenced by O’Leary’s 2011 work “Context First: A Unified Field Theory of Publishing" where he says that the containers (books) we are used to "define content in two dimensions, necessarily ignoring that which cannot or does not fit" (p. 
212). O'Leary goes on to say that the 'container first' model which limits content is already obsolete (2011, p. 212). Where O'Leary doesn't heavily involve himself in the formats that the future book could take - beyond a few digital predictions regarding workflow and bundling - Bhaskar attempts to relate content to "frames". Frames are Bhaskar's term for content containers which he considered to be "not just delivery systems or packages for content but content's experimental mode” (2012, p. 84).

Frames' experimental modes can be shuffled and twisted to hold an array of content, shifting again when the content expands, as in the form of collaborative story writing communities like StoryMash, or shrinking to become packets of books delivered straight to you cell phone. If we follow Bhaskar further, we see that he breaks down digital frames to mechanisms that assist content delivery systems: screens, HTML, coding languages, fibre optic cables, electricity, and more (2012, p. 85). All of these frames play a role, however small, in defining a book within the digital environment and beyond.

Phillips too hits on the breaking apart of content and container when he describes reading onscreen by saying that the "actual experience of reading a book is already coming close to reading web pages" (2014, p. 119), where pages can be scrolled continuously and readers can find imbedded links to enrich and inform their experience. This is reminiscent of McLuhan's 1968 article 'Book Is Dead?' where he discusses the rise of 'xerography' as a way for the reader to become publisher (1968, p. 447). In expanding from the Xerox machine to the computer, he states that "the natural tendency of any new technology is to be given the job of the old one, and this is very true of the computer" (1968, p. 448). This echoes a theme in his book The Medium is the Massage, in which he describes the phenomenon of the rear-view mirror where, "When faced with a totally new situation, we tend to always attach ourselves to the objects, to 
the flavor of the most recent past. We look at the present through a rear-view mirror" (McLuhan \& Fiore, 1968, pp. 74-75).

Hitchens inadvertently points out a modern incarnation of the rear-view mirror effecting eBooks when he says "most eBooks are functionally the same as reading a print book" (2014, p. 13). To highlight lean back technology, akin to McLuhan's rearview mirror, Phillips mentions the skeuomorphic design of the iPad, which relies on a wooden-styled bookshelf to hold a user's books (2014, p. 36). In fact, most eBook readers, platforms, and apps have embraced print book-centric functionality, such as white reading screens and page turning visuals and sounds, that serve no purpose other than to allow the reader to connect to their current media through attributes of an older one. The rear-view mirror also has an effect on how a book is defined, but, we must be careful to not limit the definition of the book to only include those already existing technologies, and instead, to open it up to future forms of framed content.

Today, the book has moved beyond the eBook to encompass a variety of ePublications facilitated by advances in media and digitally social technologies, echoing Foucault's words that "its unity is variable and relative" $(1989$, p. 23). In his article "Evolution of the Book Publishing Industry", Keh is forward thinking when he describes how, "In the information age, the publisher no longer views himself as the purveyor of physical products, but of ideas and information. The publisher's asset lies in the contents, to which he adds value by providing them in different formats" (1998, p. 118). Keh's observations are relevant today as the current publishing model continues to slowly develop and expand both vertically and horizontally, allowing for innovative ways of connecting and controlling new content delivery technologies.

Bhaskar agrees with Keh in the idea that a publisher is a purveyor of content, but he goes further than Keh in saying that the "content is framed - packaged for 
distribution and presented to an audience - according to a model" $(2012$, p. 6). While I agree that the future of the book is content based, what Keh and Bhaskar both lack in their content-focused discussion is the integration of digitally social technology that goes beyond marketing to create a place where communities can be built and where new writing can emerge.

\section{Redefining the book in the social age}

Scholars such as Bhaskar, Keh, Phillips, and O’Leary champion the idea of content as what makes a 'book' and agree that a digital text is simply another format of that content, but they stop short of taking it forward to the next, digitally social level. Specifically, they neglect to take into account instances of disruption brought on by the rise of social networking sites that have unlimited resources, an unfathomable amount of user data, and innovative citizen authors who are willing to publish their intellectual property (in the form of written works) directly within these digital communities.

While Phillips ends The Evolution of the Book with a plea for "advocates of the [(inferred) printed] book to stand up and be counted," (2104, p. 127) Bhaskar ends his by coming slightly closer to the point by declaring that "It [publishing] is a social machine. One problem: the Machine Age has ended" (2012, p. 195). The Machine Age has ended, but publishing is no less social than it has been in centuries past, perhaps, even more so in the current digital age where the world is, as McLuhan suggests, shrinking to the size of a village (1964). Venturing further than Bhaskar, we can say that books are now social.

Using that premise as a starting point, the definition of a book must be more inclusive and open to digital changes, while being careful to not to age itself at the moment of writing. It must reflect the content created around new technologies, genres, 
and digital communities, cannot alienate certain forms, or remain prejudiced around print, distribution, or multiplication. Defining what is book is in the face of a rapidly changing and developing publishing models and digital technology is never clear-cut. Keeping that in mind, moving forward with this research, I will be defining a book as any piece of framed content that has a basis in text or image, can be reproduced, and has an element of sociality, insomuch that it has the potential to be shared or made public at some stage in its development.

This description should not be considered the final word in how a book is defined, but should be used as a guideline, a starting place from which the understanding of a book can grow alongside the publishing industry and not be relegated to the objects of the past. It will help locate the places of disruption within the discourse where the objects and artefacts of interest are giving rise to new understandings of the book within the social communities and the way these new statements influence the power structures that frame the wider industry and who has a say in the ownership of the object and the pronunciation of what can be a 'book'.

\section{References:}

Bhaskhar, M., 2013. The Content Machine: Towards a Theory of Publishing from the Printing Press to the Digital Network. Anthem Press: London.

Cope. B. \& Phillips, A., 2006. Introduction. In: Cope, B. \& Phillips, A. eds. The Future of the Book in the Digital Age. Chandos: Oxford. 
Eliot, S. \& Rose, J., 2007. Introduction. In: Eliot, S. \& Rose, J. eds. A Companion to the History of the Book. Blackwell Publishing Ltd: Oxford.

Foucault, M., 1989. The Archaeology of Knowledge. Translated from the French by A. M. Sheridan Smith. Routledge: London.

Hean, T.K., 1998. Evolution of the Book Publishing Industry: Structural Changes and Strategic Implications. Journal of Management History, Vol. 4 Iss 2 pp. 104 123.

Hitchens, A.D., 2014. eBooks: The Revolution Will Be Digitized. In: The ShenzhenUNESCO, The Shenzhen-UNESCO International Conference on "Digital Books and Future Technology". Shenzen, China. Nov. 29-30, 2014. Shenzhen: UNESCO.

Keckler, S.L., 2010. Koizora: A Mirroring of Keitai Shōsetsu In a "Novel" Approach to Modern Literature. PhD. Washington and Lee University.

Kelly, K., 2006. Scan This Book!. The New York Times Magazine, [online] Available at: http://www.nytimes.com/2006/05/14/magazine/14publishing.html?pagewant $\underline{\mathrm{ed}=2 \& \mathrm{r}=5}$. [Accessed Jan 2015].

Kendall, G. \& Wickham, G., 2003. Using Foucault's Methods. SAGE Publications, Ltd.: London. 
Kilgour, F.G., 1998. The Evolution of the Book. Oxford University Press: Oxford.

McLuhan, M. \& Fiore, Q., 2008. The Medium Is the Massage. Penguin Books: London.

McLuhan, M., 2013. Understanding Media: The Extensions of Man. GINGKO PRESS: Berkeley. (eBook).

O'Leary, B.F., 2011. Context First: A Unified Theory of Publishing. Publishing Research Quarterly, 27, pp.211-219.

Onishi, N., 2008. Thumbs Race As Japan's Best Sellers Go Cellular. The New York Times Magazine, [online] Available at: http://www.nytimes.com/2008/01/20/world/asia/20japan.html?pagewanted= all\& $r=0$. [Accessed Jan 2015].

Phillips, A., 2014. Turning the Page: The Evolution of the Book. Routledge: London \& New York.

PWC., 2015. Book Publishing: Key Insights at a Glance. [pdf] Washington: PWC. Available at: https://www.pwc.com/gx/en/global-entertainment-mediaoutlook/assets/2015/book-publishing-key-insights-3-electronic-consumerbooks-revenue.pdf. [Accessed on Jan 2015].

Stein, B., 2008. A Book Is a Place.... If:Book: A Project of the Institute of the Future 
of the Book, [blog] 29 Dec. Available at:

http://futureofthebook.org/blog/2008/12/29/a book is a place/.

Zickurh, K. \& Rainie, L., 2014. E-Reading Rises as Device Ownership Jumps. [Web Report] Washington: The PEW Research Center. Available at: http://www.pewinternet.org/2014/01/16/e-reading-rises-as-deviceownership-jumps/ [Accessed on Jan 2015]. 